\title{
Determination of Pests and Beneficial Species in Avocado Orchards in Antalya Province
}

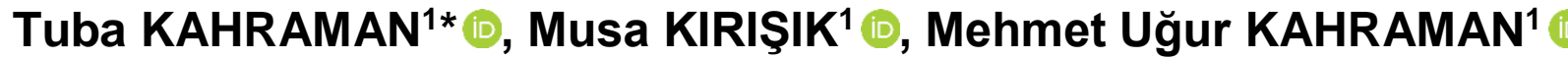

${ }^{1}$ Batı Akdeniz Agricultural Research Instiute, 07100, Antalya / Turkey

\section{Article History}

Received 12 October 2020

Accepted 29 November 2020

First Online 30 November 2020

\section{Corresponding Author}

E-mail:

tuba.sansur@tarimorman.gov.tr

\section{Keywords \\ Avocado \\ Parasitoid \\ Pest \\ Predator}

\begin{abstract}
This study was conducted to determine the pests and beneficial species found in Avocado orchards in Antalya province, Turkey. Survey studies were carried out between the years of 2018-2020 in Alanya, Aksu, Finike, Gazipaşa, Kemer, Manavgat, Muratpaşa, Serik and Kumluca districts of Antalya that have avocado production. In the surveys, visual examination, counting of the branch, knock down, and trapping methods were used. As a result of the study, 18 pest species belonging to 13 families and 6 orders and 15 beneficial species belonging to 4 orders and 5 families were determined.
\end{abstract}

\section{Introduction}

Avocado (Persea americana Mill.), is a subtropical plant that spreads over large areas of the world and stands out with its increase in production every year. Avocado, which is in high demand in international markets with its nutritious properties and distinctive taste, entered to Turkey in the early 1970s and spread along the Mediterranean coastline. Mexico ranks first in terms of avocado production in the world, while Indonesia, Peru, the Dominican Republic, and Colombia follow that respectively (FAOSTAT, 2018). In Turkey, it is grown in the coastline of Muğla, Antalya, Adana, Hatay and Mersin provinces (Table 1). The total avocado production area, which was 556 ha in 2018, has almost doubled, reaching 950 ha as of 2019 (TUIK, 2018; 2019). Antalya province in Turkey leads the avocado production at the highest rate. Antalya accounts for $70 \%$ of the avocado production area in Turkey. In Antalya, Alanya district constitutes the highest production area with $62 \%$ (TUIK, 2019). As avocado production increases over time, it is exported from Antalya province to 25 countries, including Germany, Ukraine, Bulgaria, and Greece (BAlB, 2019). Studies on the adaptation of avocado cultivars in Turkey have been conducted in Batı Akdeniz Agricultural Research Institute (BATEM) in Antalya for many years and it has been determined that Bacon, Fuerte, Hass, Zutano, and Ettinger cultivars are suitable for the region (Bayram et al., 2006). These data clearly show the importance of Antalya province in avocado production. In parallel with the intensive demand day by day, the number of avocado trees is increasing and it is thought that avocado will be as important as citrus and pomegranate in the following years.

It is estimated that pests and beneficial species are intense due to the increase of production areas of Avocado, the suitability of the climate conditions of Antalya province for insect populations, and the lack of chemical control yet. Bayram (2010) reported that the Mediterranean medfly, thrips, scale insects, mealybugs, and lemon rat are among the common pests. However, there is no detailed study on this issue in Turkey. The aim of this study was to identify pests and beneficial species as the first step in the control of avocado pests. Most species obtained as a result of the research will be the first record for the avocado fauna of Turkey. 
Table 1. Avocado presence and production in Turkey by provinces (TUIK, 2019)

\begin{tabular}{lcccr}
\hline Province & $\begin{array}{c}\text { Number of trees at } \\
\text { fruiting age }\end{array}$ & $\begin{array}{c}\text { The number of trees in } \\
\text { not fruiting }\end{array}$ & $\begin{array}{c}\text { Total area of orchards } \\
\text { (ha) }\end{array}$ & $\begin{array}{c}\text { Production amount } \\
\text { (tons) }\end{array}$ \\
\hline Adana & - & 2180 & 6.7 & - \\
Antalya & 60986 & 52455 & 659.5 & 3409 \\
Hatay & 293 & - & 0.8 & 23 \\
Mersin & 9230 & 77682 & 276.9 & 699 \\
Muğla & 2010 & 1050 & 5.2 & 78 \\
\hline
\end{tabular}

Table 2. Number of trees examined according to orchard size (Lazarov and Grigorov, 1961)

\begin{tabular}{ll}
\hline Total number of trees in survey orchards & Number of trees examined \\
\hline $1-20$ & All trees \\
$21-70$ & $10-30$ \\
$71-150$ & $31-40$ \\
$151-500$ & $41-80$ \\
$501-1000$ & $15 \%$ of total trees \\
More than 1000 & $5 \%$ of total trees \\
\hline
\end{tabular}

In this study, it was aimed to identify pests and beneficial species in avocado orchards by conducting surveys during 2018-2020, spreading Alanya, Aksu, Finike, Gazipaşa, Kemer, Manavgat, Muratpaşa, Serik and Kumluca districts of Antalya province in Turkey. The data obtained from the study, can be used as preliminary information both in the pest control and in the use of biological control factors.

\section{Material and Methods}

The material of the study consists of avocado orchards in Alanya, Aksu, Finike, Gazipaşa, Kemer, Manavgat, Muratpaşa, Serik, and Kumluca districts in Antalya province, the tools used in the survey studies, culture containers, labels, pests and beneficial species, traps, chemicals and consumables used in preparing insects for diagnosis, and equipment.

\subsection{Survey studies}

The studies were conducted between March and November in avocado production areas in Alanya, Aksu, Finike, Gazipaşa, Kemer, Manavgat, Muratpaşa, Serik and Kumluca districts in Antalya province between the years of 2018 and 2020 . Surveys were carried out at non-periodic intervals and it was noted that no pesticide was applied out in the selected orchards. In the survey studies, $0.01 \%$ of the total avocado area was included and studies were carried out in a total of 30 orchards. The number of trees to be examined according to the size of the orchard was determined according to the method of Lazarov and Grigorov (1961) (Table 2).

\subsection{Determination of pests and beneficial species}

Taking into account the phenology of the plants in the survey areas and labour force, sampling was carried out at non-periodic intervals between March and November by visual inspection, knock down, counting of branch, and trapping method (Anonymous, 2017).

Visual examination method: According to the phenological period of the plant, a total of 100 plant parts, consisting of 10 parts (buds, flowers, leaves, and fruits) from 10 trees, were randomly selected and the pests and beneficial species were collected and recorded.

Knock down method: This method was used with Steiner funnel (Steiner, 1960). The branches, which in the different directions of the trees randomly selected to represent the avocado orchard, were hit twice with a stick with a rubber tube on the end and hit 100 times in total and the pests and beneficial species that fell on the Steiner funnel were collected with an aspirator and recorded.

Branch counting method: $20-25 \mathrm{~cm}$ long branches and shoots were collected from different sides of five trees to identify scale insects.

Trapping method: The delta type trap containing the Mediterranean fruit fly pheromone and yellow and blue sticky traps were hung in the orchard in the south direction of the trees and at a height of about $1.5-2.0 \mathrm{~m}$ from the ground, and the insects caught in the traps were brought to the laboratory.

\subsection{Laboratory studies}

Adults were collected and brought to the laboratory in an icebox, prepared for diagnosis and sent to subject experts. Pre-adult periods were cultured in the laboratory and sent to the diagnosis in the same way when they became adult. Furthermore, parasitized individuals were brought to the laboratory and cultured for parasitoid emergence and sent for diagnosis.

\section{Results and Discussion}

As a result of surveys, 18 pest species belonging to 13 families and 6 orders and 15 beneficial species belonging to 5 families and 4 orders were identified. 
Table 3. Pests found in avocado orchards

\begin{tabular}{lll}
\hline Order & Family & Species \\
\hline & Aphididae & Aphis (Toxoptera) aurantii (Boyer de Fonscolombe) \\
& Myzus (Nectarosiphon) persicae (Sulzer) \\
& Diaspididae & Chrysomphalus dictyospermi (Morgan) \\
& Chrysomphalus aonidum (Linnaeus) \\
Hemiptera & Coccus hesperidum (Linnaeus) \\
& Ceroplastes floridensis (Comstock) & Fieberiella oenderi (Dlabola) \\
& Cicadellidae & Balclutha frontalis (Ferrari) \\
& Issidae & Agalmatium bilobum (Fieber) \\
& Margarodidae & Icerya purchasi Mask. \\
& Pseudococcidae & Pseudococcus viburni (Signoret) \\
\hline Coleoptera & Aleyrodidae & Trialeurodes vaporariorum (Westwood) \\
\hline Thysanoptera & Cerambycidae & Batocera rufomaculata (De Geer) \\
\hline Diptera & Thripidae & Thrips pillichi (Priesner) \\
\hline Acarina & Heliothrips haemorrhoidalis (Bouché) \\
\hline Epulmonata & Acaridae & Ceratitis capitata (Wiedemann) \\
\hline
\end{tabular}

Table 4. Beneficial species found in avocado orchards

\begin{tabular}{lll}
\hline Order & Family & Species \\
\hline & & Stethorus punctillum Weise \\
& & Serangium parcesetosum Sicard \\
& & Scymnus rubromaculatus (Goeze) \\
Coleoptera & Oenopia conglobata (Linnaeus) \\
& Coccinellidae & Scymnus auritus (Thunberg) \\
& & Nephus nigricans (Weise) \\
& Adalia bipunctata (Linnaeus) \\
& Chilocorus bipustulatus (L.) \\
& & Hippodamia variegata (Goeze) \\
Neuroptera & Coccinella septempunctata (Linnaeus) \\
\hline Hymenoptera & Coniopterygidae & Chrysoperla carnea (Stephens) \\
\hline \multirow{2}{*}{ Acarina } & Conwentzia pineticola (Enderlein) \\
\hline
\end{tabular}

Thrips pillichi Priesner, 1924, (Thysanoptera: Thripidae), Fieberiella oenderi Dlabola, 1985, Balclutha frontalis Ferrari, 1882 (Hemiptera: Cicadellidae), Agalmatium bilobum Fieber, 1877 (Hemiptera: Issıdae), Eobania vermiculata (Müller) (Eupulmonata: Helicidae) and Pseudococcus viburni (Hemiptera: Pseudococcidae) species were recorded as the first record of avocado in the world, while all species except Ceratitis capitata in Turkey were recorded as the first record for avocado cultivation.

Pests and beneficial species found in avocado orchards of Antalya province are given in Table 3 and 4. Myzus persicae and Aphis aurantii species, which are two aphid species determined in avocado orchards in Antalya province, are widely found in many cultivated plants in Turkey (Sarac et al., 2015). Furthermore, they are among the known avocado pests in the world (CABI, 2019).

The most common pest group in avocado orchards are scale insects. Chrysomphalus dictyospermi and Chrysomphalus aonidum are avocado pests identified as in the world (Kondo and Muñoz, 2016). In Turkey, it has been detected in a large number of hosts in the Mediterranean,
Aegean, Marmara, and Black Sea regions (Kaydan et al., 2013; Çalışkan Keçe and Ulusoy, 2017; Yaşar and Erözmen, 2018). C. hesperidum, Ceroplastes floridensis and Icerya purchasi (cottony cushion scale) are known as common citrus pests in Antalya (Göl and Karaca, 2016). In a study conducted in Colombia, it was reported that these pests were identified in avocado areas as well (Kondo and Muñoz, 2016). Moreover, whiteflies are among the important pests that have a wide host range in Turkey. Trialeurodes vaporariorum species was found in the study carried out and this species is among the avocado pests known in the world (CABI, 2019; García-Palacios et al., 2020).

Fieberiella oenderi, B. frontalis and A. bilobum species belong to Cicadellidae and Issidae families were found in Antalya and Turkey fauna (Demir, 2008). In the world, no information has been reached that these species, which are harmful to different hosts and avocados.

Pseudococcus viburni is an important pest species in orchards in the Black Sea Region, Istanbul and Ankara provinces in Turkey (Telli and Yiğit, 2019). However, this species has not been determined in avocado orchards. 
Doğanlar and Yiğit (2002) found that black vine thrips, Retithrips syriacus (Mayet) (Thysanoptera: Thripidae), a fruit and vineyard pest detected in Hatay, were fed and reproduced in avocado fruits as a result of laboratory studies. In our study, two different thrips species, T. pillichi and Heliothrips haemorrhoidalis, were found. Moreover, $H$. haemorrhoidalis species is known as an important thrips species in avocado in the world (Stevens et al., 1999; Larral and Lipa, 2007; Denmark and Fasulo, 2010). In Turkey, this species was first recorded as an important kiwi pest in a study conducted in Rize province in 2009-2010 (Ülgentürk et al., 2011). Similarly, $T$. pillichi is found in the fauna of Turkey and is not known as an avocado pest in the world (Nickle, 2008; Tunç and Hastenpflug - Vesmanis, 2016).

Furthermore, Batocera rufomaculata, which was detected in avocado orchards in Gazipaşa district in 2020, entered Turkey as a fig pest in 2000 (Tozlu and Özbek, 2000). In the world, it is one of the hosts of avocado trees (Mane and Gaikwad, 2018).

Tiring and Satar (2017) stated that in their study to determine the population fluctuation of the $C$. capitata species in avocado, peach, and fig orchards, $C$. capitata has been identified with the culturing of infected fruits from the avocado orchard. In the present study, C. capitata was found in traps in avocado orchards in Serik and Alanya districts. Besides, it is included among avocado pests in the world (De Graaf, 2009; EPPO, 2011).

Tyrophagus putrescentiae mite has been identified in stored products in Turkey, and no information has been found on its detection in avocado areas. Moreover, it was detected in avocado orchards in a study conducted in Mexico in 2017 (Genç and Özar, 1986; Sandoval-Cornejo et al., 2019).

Eobania vermiculata (Müller) (Eupulmonata: Helicidae) has been found to cause damage in peach and nectarine orchards in Adana and Mersin provinces (Hazır and Ulusoy, 2012). This pest is generally found in coastal areas, dry vegetation, vineyards, and agricultural areas in the world (Ronsmans and Van den Neucker, 2016). As for the beneficial species found in avocado orchards during the surveys, all detected species are widely found in the Turkish fauna.

\section{Conclusion}

Among the pests identified in the surveys, it was observed that the population of most pests is low. Hence, it is believed that the presence of predators and parasitoids found in nature keeps these pests in balance. Considering that there is no licensed plant protection product in avocado, it is thought that many pests will fall below the economic loss threshold if natural enemies are protected. However, for pests that have a high population and require to be controlled, different controlling techniques should be studied within the scope of an integrated pest management (IPM) program. These controlling methods should be the least harmful to the environment and natural enemies.

\section{Acknowledgements}

The authors thank to Prof. Dr. Ahmet BEYARSLAN (Trakya University), Prof. Dr. Ekrem ATAKAN (Çukurova University), Assoc. Prof. Emine DEMIR ÖZDEN (Düzce University), Dr. Emine TOPUZ (Bati Akdeniz Agricultural Research Institute), Heval DiLER (Plant Protection Central Research Institute), Dr. Işıl ÖZDEMiR (Plant Protection Central Research Institute), Prof. Dr. Göksel TOZLU (Atatürk University), Dr. Medine BASAR (Aksu District Directorate of Agriculture and Forestry), Prof. Dr. Miktat DOGANLAR (Mustafa Kemal University), Prof. Dr. Nedim UYGUN (Cukurova University), Prof. Dr. Savas CANBULAT (Kastamonu University), Prof. Dr. Selma ULGENTURK (Ankara University), Prof. Dr. Sultan COBANOGLU (Ankara University) and Assoc. Prof. Umit KEBAPCI (Mehmet Akif University) for identification of pests and natural enemies.

\section{References}

Anonymous, (2017). Technical Instruction of Integrated Control of Citrus Plant. Tarımsal Araştırmalar ve Politikalar Genel Müdürlüğü Bitki Sağlığı Araştırmaları Daire Başkanlığı. Ankara, 2017 (In Turkish).

BAï, (2019). West Mediterranean Exporters Association. https://www.baib.gov.tr/tr/. Date accessed: September 02, 2020.

Bayram, S., Arslan, A., \& Turgutoğlu, E. (2006). Cruising and proposed some varieties in Turkey. Derim, 23:113.

Bayram, S. (2010). Avocado cultivation. Batı Akdeniz Tarımsal Araştırma Enstitüsü, p. 147, Antalya, (in Turkish).

CABI, 2019. Persea americana (Avocado). http://www.cabi.org/isc/datasheet/39380. Date accessed: September 09, 2020.

Çalışkan Keçe, A.F., \& Ulusoy, M.R. (2017). Armored scale insects (Hemiptera: Sternorrhyncha: Diaspididae) on ornamental plants in Adana, Turkey. Turkish Journal of Entomology, 41:333-346.

De Graaf, J. (2009). Host status of avocado ('Hass') to Ceratitis capitata, Ceratitis rosa, and Ceratitis cosyra (Diptera: Tephritidae) in South Africa. Journal of Economic Entomology, 102:1448-1459.

Demir E. (2008). The Fugoromorpha and Cicadomorpha of Turkey, Part I: Mediterranean region (Hemiptera). Munis Entomology \& Zoology, 3:447-522.

Denmark, H.A, \& Fasulo, T.R. (2010). Greenhouse thrips, Heliothrips haemorrhoidalis (Bouché) Insecta: Thysanoptera: Thripidae). UF/IFAS Publication EENY-75. University of Florida, Gainesville, USA.

Doğanlar, M., \& Yiğit, A. (2002). A new potential pest for orchards and vineyards: Black vine thrips, Retithrips syriacus (Mayet) (Thysanoptera: Thripidae) in Hatay]. Turkish Journal of Entomology, 26:283-294.

EPPO, (2011). Ceratitis capitata. Bulletin OEPP/EPPO Bulletin 41:340-346.

FAOSTAT (2018). Statistical Database of the Food and Agriculture Organization of the United Nations. http://www.fao.org/faostat/en/\#data/QC. Date accessed: September 02, 2020.

García-Palacios, D., Martínez, N.B., Steelers, M., \& De Jesús C,G. (2020). Morphological and molecular identification of whiteflies associated with avocado at 
Morelos, Mexico. Southwestern Entomologist, 45:109-122.

Genc, H., \& Ozar, A.I. (1986). Preliminary investigations on the mites found on stored products in Izmir. Turkish Journal of Plant Protection, 10:175-183.

Göl, V., \& Karaca, İ. (2016). Populations of important insects pests and beneficial insects at orange orchards in Antalya Province]. Süleyman Demirel University Journal of Natural and Applied Sciences, 20:188-196.

Hazır, A., \& Ulusoy, M.R. (2012). Pest, parasitoid and predator species determined in peach and nectarine orchards in Adana and Mersin provinces. Turkish Journal of Biological Control, 3:157-168.

Kaydan, M.B., Ülgentürk, S., \& Erkiliç, L. (2013). Checklist of Turkish Coccoidea (Hemiptera: Sternorryncha) species. Turkish Journal of Entomology, 3:157-182.

Kondo, T., \& Muñoz, J.A. (2016). Scale insects (Hemiptera: Coccoidea) associated with avocado crop, Persea americana Mill. (Lauraceae) in Valle del Cauca and neighboring departments of Colombia. Insecta Mundi, 0457:1-14.

Larral, P., \& Ripa, R. (2007). Evaluation of pesticide effectiveness on the control of Heliothrips haemorrhoidalis (Thysanoptera: Thripidae) on avocado trees (Persea americana Mill.). Proceedings of the VI World Avocado Congress, Chile.

Lazarov, A., \& Grigorov, P. (1961). Karantina Rastenijata. Zemizdat, Sofia, p: 258.

Mane, Y.K., \& Gaikwad, S.M. (2018). Variation in size of Batocera rufomaculata (De Geer, 1755) (Coleoptera: Cerambycidae) in Kolhapur District, Maharashtra, India. European Journal of Biomedical and Pharmaceutical Sciences, 5:769-770.

Nickle, D.A. (2008). Commonly intercepted thrips at U.S. ports-of-entry from Africa, Europe, and the Mediterranean. III. The genus Thrips Linnaeus, 1758 (Thysanoptera: Thripidae). Proceedings of the entomological Society of Washington, 110:165-185.

Ronsmans, J., \& Van Den Neucker, T. (2016). A persistent population of the chocolate-band snail Eobania vermiculata (Gastropoda: Helicidae) in Belgium. Belgian Journal of Zoology, 146:66-68.

Sandoval-Cornejo, E.N., Estrada-Venegas, E.G., Equihua-Martínez, A., Romero-Nápoles, J., \&
Alvarado-Rosales, D. (2019). Mites associated with ambrosia and bark beetles (Curculionidae: Scolytinae) in avocado orchards in Michoacan, Mexico. Acarological Studies, 1:174-175.

Saraç, I., Özdemir, I., \& Karaca, İ. (2015). Aphids species in citrus orchards of Antalya province. Munis Entomology \& Zoology, 10:358-369.

Steiner, N. (1962). Methoden zur untersuchung der population dynamikin obstanlangen. Entomophaga, 7:207-214

Stevens, P., Froud, K., \& Mills, E. (1999). Effects of greenhouse thrips (Heliothrips haemorrhoidalis) lifestage, density and feeding duration on damage to avocado fruit. Revista Chapingo Serie Horticultura, 5:287-300

Telli, S., \& Yiğit, A. (2019). Pseudococcid (Hemiptera) species injurious in fruit trees in Turkey and their natural enemies. Turkish Journal of Biological Control, 10:41-59.

Tiring, G., \& Satar, S. (2017). Population fluctuation of Ceratitis capitata (Wiedemann) (Diptera: Tephritidae) in some fruit orchards. Turkish Bulletin of Entomology, 7: 29-37.

Tozlu, G., \& Özbek, H. (2000). The Tropical Fig Borer, Batocera rufomaculata (Coleoptera cerambycidae), new for Turkey. Zoology in The Middle East, 20:21124.

Tunç, İ., \& Hastenpflug-Vesmanis, A. (2016). Records and checklist of Thysanoptera in Turkey. Turkish Journal of Zoology, 40:769-778.

TÜIK (2018). The Turkish Statistical Institute. https://biruni.tuik.gov.tr/medas/?kn=92\&locale=tr. Date accessed: September 02, 2020.

TÜIK (2019). The Turkish Statistical Institute. https://biruni.tuik.gov.tr/medas/?kn=92\&locale=tr. Date accessed: September 02, 2020.

Ülgentürk, S., Ayhan, B., Karakaya, A., \& Tunç, İ. (2011). A new kiwifruit pest in Turkey: Greenhouse thrips Heliothrips haemorrhoidalis (Bouché) (Thysanoptera: Thripidae]. Journal of Agricultural Faculty of Bursa Uludag University, 25:143-149.

Yaşar, B., Erözmen, K. (2018). Determination of Diaspididae species (Hemiptera: Coccomorpha) on fruit trees in Balıkesir. Süleyman Demirel University Journal of Natural and Applied Sciences, 22:172-181. 